\title{
Increased Number of Mast Cells in Epicardial Adipose Tissue of Cardiac Surgery Patients With Coronary Artery Disease
}

\author{
Karolína ROZSÍVALOVÁ ${ }^{1}$, Aneta PIERZYNOVÁ ${ }^{1}$, Helena KRATOCHVÍLOVÁ ${ }^{2,3}$, Jaroslav \\ LINDNER $^{4}$, Michal LIPŠ ${ }^{5}$, Tomáš KOTULÁK ${ }^{5}$, Peter IVÁK ${ }^{6}$, Ivan NETUKA ${ }^{6}$, Martin \\ HALUZÍK ${ }^{2,3}$, Tomáš KUČERA ${ }^{1}$
}

${ }^{1}$ Institute of Histology and Embryology, First Faculty of Medicine, Charles University, Prague, Czech Republic, ${ }^{2}$ Institute of Medical Biochemistry \& Laboratory Diagnostics, First Faculty of Medicine, Charles University and General University Hospital, Prague, Czech Republic, ${ }^{3}$ Centre for Experimental Medicine and Diabetes Centre, Institute for Clinical and Experimental Medicine, Prague, Czech Republic, ${ }^{4}$ Second Department of Surgery - Department of Cardiovascular Surgery, First Faculty of Medicine, Charles University and General University Hospital, Prague, Czech Republic, ${ }^{5}$ Department of Anesthesiology, Resuscitation and Intensive Medicine, First Faculty of Medicine, Charles University and General University Hospital, Prague, Czech Republic, ${ }^{6}$ Department of Cardiovascular Surgery, Institute for Clinical and Experimental Medicine, Prague, Czech Republic

Received October 18, 2019

Accepted May 25, 2020

Epub Ahead of Print June 25, 2020

\section{Summary}

Chronic inflammation of adipose tissue is associated with the pathogenesis of cardiovascular diseases. Mast cells represent an important component of the innate defense system of the organism. In our work, we quantified mast cell number in epicardial adipose tissue (EAT), subcutaneous adipose tissue (SAT), and right atrial myocardium (RA) in patients undergoing open heart surgery $(n=57)$. Bioptic samples of EAT $(n=44)$, SAT $(n=42)$ and RA ( $n=17)$ were fixed by $4 \%$ paraformaldehyde and embedded into paraffin. An anti-mast cell tryptase antibody was used for immunohistochemical detection and quantification of mast cells. We also demonstrated immunohistochemically the expression of CD117 and chymase markers. In EAT of patients with coronary artery disease (CAD), higher incidence of mast cells has been found compared to patients without CAD (3.7 \pm 2.6 vs. $2.1 \pm 1.2$ cells $/ \mathrm{mm}^{2}$ ). In SAT and RA, there was no difference in the number of mast cells in CAD and non-CAD patients. Mast cells in SAT, EAT and RA expressed CD117 and chymase. An increased incidence of mast cells in EAT of CAD patients may indicate the specific role of these inflammatory cells in relation to EAT and coronary arteries affected by atherosclerosis.

\section{Key words}

Chronic inflammation • Atherosclerosis • Myocardium • Obesity • Tryptase

\section{Corresponding author}

Tomáš Kučera, Institute of Histology and Embryology, First Faculty of Medicine, Charles University, Albertov 4, Prague 2, 12000, Czech Republic. E-mail: tkucer@If1.cuni.cz

\section{Introduction}

Under pathological conditions such as obesity or coronary artery disease (CAD), adipose tissue is in the state of low-grade chronic inflammation (Dam et al. 2016). Such inflammation is manifested by an altered secretion of adipokines and infiltration by several different populations of inflammatory cells (Mraz and Haluzik 2014). White adipose tissue is distributed in the body in the form of several distinct depots, which are traditionally divided into subcutaneous (SAT) and visceral adipose tissue (VAT), which also includes epicardial adipose tissue (EAT) (Lee et al. 2013). The

PHYSIOLOGICAL RESEARCH • ISSN 1802-9973 (online) 
cell type characteristic for this tissue is the unilocular adipocyte, but these cells are accompanied by a huge number of stromal cells including preadipocytes, endothelial cells, perivascular cells and there is a discrete population of immune cells even in normal conditions. EAT is a special adipose tissue depot, due to its intimate contact with coronary arteries and its vicinity to myocardium directly underneath epicardial fat tissue layer without any additional connective tissue barrier (Matloch et al. 2018a). Like adipose tissue in other locations, EAT is during healthy conditions a source of beneficial adipokines such as adiponectin (Fitzgibbons and Czech 2014). In CAD, EAT increases its size and becomes dysfunctional as it starts to produce a different set of adipokines and pro-inflammatory cytokines that can further potentiate atherogenic process in the coronary arteries (Matloch et al. 2018b, Mazurek et al. 2003, Iacobellis 2016). These cytokines are mainly produced by infiltrating inflammatory cells such as macrophages and lymphocytes, which are elevated in EAT of CAD patients (Hirata et al. 2011, Mraz et al. 2019). Mast cells are cells of hemopoetic origin and constitute an important part of the innate immune response (da Silva et al. 2014). These cells are found in most organs and are mainly associated with the connective tissue, often near blood vessels. Mast cells are traditionally described as cells involved in allergic response due to their $\mathrm{Fc}$ receptors for $\mathrm{IgE}$ immunoglobulins, but their physiological and pathological functions extend beyond this activity. Their role is mainly mediated by secreted factors, some of which are together with histamine and heparin stored as preformed substances in granules and many others including various cytokines and growth factors (eg. IL-1beta, CCL2, TNF-alpha or bFGF) are synthesized de novo upon activation (Krystel-Whittemore et al. 2015). Based on the content of chymase, tryptase or both, they can be divided into $\mathrm{MC}_{\mathrm{T}}$ population typical for the mucosal lining of the respiratory tract and $\mathrm{MC}_{\mathrm{TC}}$ population found in the connective tissue of the skin (da Silva et al. 2014). Importantly, mast cells have been also implicated in chronic low-grade inflammation of adipose tissue and in atherosclerotic cardiovascular disease (Kovanen and Bot 2017, Zelechowska et al. 2018). An increase of mast cell numbers in SAT was reported in obese patients (Liu et al. 2009, Spencer et al. 2014). Previous study suggested that mast cells accumulate in EAT (Mazurek et al. 2003) of CAD patients. The quantification of mast cell population in EAT of CAD patients have not been performed yet. Thus, the objective of this study was to determine the amount and phenotype of mast cells in EAT, SAT and myocardium of CAD patients and non-CAD patients, who underwent elective heart surgery. In addition, we evaluated the effect of other concomitant pathological conditions, namely obesity and type 2 diabetes mellitus (T2DM). We hypothesized that similarly to other inflammatory cells, mast cell numbers are increased in EAT of CAD patients and this way they can contribute to the chronic low-grade inflammation in EAT.

\section{Methods}

\section{Patients}

All patients $(n=57)$ were scheduled for elective cardiovascular surgery. All participants signed written informed consent prior to the enrollment into the study. The study was approved by Human Ethics Review Board, First Faculty of Medicine and General University Hospital, Prague, Czech Republic and was performed in accordance with the guidelines proposed in Declaration of Helsinki (2000) of the World Medical Association. In this study group, there were obese $(n=24)$ and non-obese patients $(n=33)$, CAD $(n=35)$ and non-CAD patients $(n=22)$ and T2DM $(n=18)$ and non-T2DM patients $(n=39)$. Adult age and coronary artery disease or valvular disorder scheduled for elective coronary artery bypass graft implantation (CABG), valvular replacement, or valvuloplasty were selected as study inclusion criteria, while all acute cardiosurgical procedures along with the inability or refusal to provide written informed consent were defined as exclusion criteria. We used 17 samples of the RA, 44 samples of EAT, and 42 samples of SAT obtained from heart surgery. Characteristics of the study population and comparison between non-CAD and CAD (scheduled for CABG) group are shown in Table 1. The comparisons of study subjects divided according to the presence or absence of T2DM (based on the diagnosis in the patient's documentation) are shown in the Table 2. Characteristics of the study population and comparison between non-obese $(\mathrm{BMI}<30)$ and obese (BMI> 30) group are shown in Table 3.

\section{Blood and tissue sampling}

Blood samples were taken at the beginning of surgery after overnight fasting. Histopathological and morphological analyses were performed blindly with respect to biochemical and biometric parameters as well as to clinical diagnosis. 
Table 1. Characteristics of patients - baseline clinical and laboratory parameters.

\begin{tabular}{|c|c|c|c|c|}
\hline Characteristics & All patients $(n=57)$ & Non-CAD $(n=22)$ & CAD $(n=35)$ & p-value \\
\hline Age (range) & $67.2(39.6-84.3)$ & $66.7(39.6-77.4)$ & $67.5(54.7-84.3)$ & 0.789 \\
\hline Males, $n(\%)$ & $42(74)$ & $15(68)$ & $27(77)$ & 0.454 \\
\hline Weight (kg) & $88 \pm 17$ & $89 \pm 20$ & $88 \pm 16$ & 0.805 \\
\hline$B M I\left(\mathrm{~kg} / \mathrm{m}^{2}\right)$ & $29.6 \pm 5$ & $29.5 \pm 4.6$ & $29.7 \pm 5.2$ & 0.915 \\
\hline Waist circumference (cm) & $104 \pm 13$ & $105 \pm 14$ & $104 \pm 13$ & 0.759 \\
\hline Hip circumference $(\mathrm{cm})$ & $108 \pm 9$ & $107 \pm 9$ & $108 \pm 9$ & 0.753 \\
\hline$W H R$ & $0.97 \pm 0.07$ & $0.98 \pm 0.07$ & $1.0 \pm 0.08$ & 0.458 \\
\hline Atrial fibrillation (\%) & $4(7)$ & $1(5)$ & $3(9)$ & 0.562 \\
\hline Arterial hypertension (\%) & $38(67)$ & $12(55)$ & $26(74)$ & 0.124 \\
\hline$T 2 D M(\%)$ & $18(32)$ & $7(32)$ & $11(31)$ & 0.975 \\
\hline$H D L(\mathrm{mmol} / \mathrm{l})$ & $1.1 \pm 0.4$ & $1.0 \pm 0.3$ & $1.1 \pm 0.4$ & 0.247 \\
\hline$L D L(\mathrm{mmol} / \mathrm{l})$ & $2.2 \pm 0.7$ & $2.5 \pm 0.9$ & $2.1 \pm 0.6$ & 0.115 \\
\hline Triglycerides $(\mathrm{mmol} / \mathrm{l})$ & $1.5 \pm 0.8$ & $1.5 \pm 0.6$ & $1.4 \pm 0.9$ & 0.689 \\
\hline Total cholesterol (mmol/l) & $3.97 \pm 0.9$ & $4.2 \pm 1$ & $3.9 \pm 0.8$ & 0.301 \\
\hline Fasting glucose (mmol/l) & $6.9 \pm 2$ & $7.2 \pm 2.4$ & $6.8 \pm 1.7$ & 0.541 \\
\hline $\mathrm{HbAlc}(\mathrm{mmol} / \mathrm{mol})$ & $43 \pm 10.1$ & $43.2 \pm 10.6$ & $42.9 \pm 9.9$ & 0.935 \\
\hline$C R P(\mu g / m l)$ & $7.1 \pm 10.1$ & $3.3 \pm 2$ & $8.8 \pm 11.7$ & 0.162 \\
\hline Atherogenity index & $2.6 \pm 0.9$ & $3 \pm 1.2$ & $2.5 \pm 0.7$ & 0.175 \\
\hline
\end{tabular}

Values are mean \pm standard deviation (SD) unless otherwise indicated. AF = atrial fibrillation; $B M I=$ body mass index; WHR $=$ waistto-hip ratio, $\mathrm{HDL}=$ high-density lipoprotein; $\mathrm{LDL}=$ low-density lipoprotein; $\mathrm{CRP}=\mathrm{C}$-reactive protein; HbA1c = glycated hemoglobin. * significant results. Student's t-test and Chi-square test.

Table 2. Characteristics of patients - baseline clinical and laboratory parameters.

\begin{tabular}{|c|c|c|c|c|}
\hline Characteristics & All patients $(n=57)$ & Non-T2DM (n=39) & T2DM (n=18) & p-value \\
\hline Age (range) & $67.2(39.6-84.3)$ & $67.1(39.6-84.3)$ & $67.4(54.7-78.3)$ & 0.876 \\
\hline Males, $n(\%)$ & $42(74)$ & $29(74)$ & $13(72)$ & 1.000 \\
\hline Weight (kg) & $88 \pm 17$ & $87 \pm 18$ & $91.5 \pm 16.4$ & 0.370 \\
\hline$B M I\left(\mathrm{~kg} / \mathrm{m}^{2}\right)$ & $29.6 \pm 5$ & $28.8 \pm 4.9$ & $31.2 \pm 5.1$ & 0.109 \\
\hline Waist circumference (cm) & $104 \pm 13$ & $100.9 \pm 12.5$ & $109.2 \pm 12.1$ & $0.041 *$ \\
\hline Hip circumference $(\mathrm{cm})$ & $108 \pm 9$ & $106 \pm 8.3$ & $109.9 \pm 9.3$ & 0.159 \\
\hline$W H R$ & $0.97 \pm 0.07$ & $0.95 \pm 0.08$ & $1.0 \pm 0.06$ & 0.073 \\
\hline Atrial fibrillation (\%) & $4(7)$ & $4(10)$ & 0 & 0.297 \\
\hline Arterial hypertension (\%) & $38(67)$ & $22(56)$ & $16(89)$ & $0.018^{*}$ \\
\hline$C A D(\%)$ & $35(61)$ & $24(62)$ & $11(61)$ & 1.000 \\
\hline$H D L(\mathrm{mmol} / \mathrm{l})$ & $1.1 \pm 0.4$ & $1.1 \pm 0.3$ & $1.2 \pm 0.5$ & 0.322 \\
\hline$L D L(\mathrm{mmol} / \mathrm{l})$ & $2.2 \pm 0.7$ & $2.2 \pm 0.9$ & $2.2 \pm 0.5$ & 0.989 \\
\hline Triglycerides (mmol/l) & $1.5 \pm 0.8$ & $1.4 \pm 0.5$ & $1.6 \pm 1.0$ & 0.359 \\
\hline Total cholesterol (mmol/l) & $4 \pm 0.9$ & $3.9 \pm 1$ & $4.0 \pm 0.8$ & 0.576 \\
\hline Fasting glucose $(\mathrm{mmol} / \mathrm{l})$ & $6.9 \pm 2$ & $5.8 \pm 0.8$ & $8.6 \pm 2.1$ & $<0.001^{*}$ \\
\hline $\mathrm{HbAlc}(\mathrm{mmol} / \mathrm{mol})$ & $43 \pm 10.1$ & $36.8 \pm 3.9$ & $52.8 \pm 9.1$ & $<0.001 *$ \\
\hline$C R P(\mu g / m l)$ & $7.1 \pm 10.1$ & $6.7 \pm 10.4$ & $7.8 \pm 10.3$ & 0.776 \\
\hline Atherogenity index & $2.6 \pm 0.9$ & $2.6 \pm 0.9$ & $2.7 \pm 1.0$ & 0.761 \\
\hline
\end{tabular}

Values are mean \pm standard deviation $(\mathrm{SD})$ unless otherwise indicated. $\mathrm{AF}=$ atrial fibrillation; BMI = body mass index; WHR = waistto-hip ratio, $\mathrm{HDL}=$ high-density lipoprotein; $\mathrm{LDL}=$ low-density lipoprotein; $\mathrm{CRP}=\mathrm{C}$-reactive protein; ApoB = apolipoprotein $\mathrm{B}$; $\mathrm{HbA} 1 \mathrm{C}$ = glycated hemoglobin. * significant results. Student's t-test and Chi-square test. 
Table 3. Characteristics of patients - baseline clinical and laboratory parameters.

\begin{tabular}{|c|c|c|c|c|}
\hline Characteristics & All patients $(n=57)$ & Non-obese $(n=33)$ & Obese $(n=24)$ & p-value \\
\hline Age (range) & $67.2(39.6-84.3)$ & $69.9(39.6-84.3)$ & $63.5(40.7-75.1)$ & $0.006^{*}$ \\
\hline Males, $n(\%)$ & $42(74)$ & $24(73)$ & $18(75)$ & 1.000 \\
\hline Weight $(\mathrm{kg})$ & $88 \pm 17$ & $79 \pm 11$ & $102 \pm 15.2$ & $<0.001 *$ \\
\hline$B M I\left(\mathrm{~kg} / \mathrm{m}^{2}\right)$ & $29.6 \pm 5$ & $26.2 \pm 2.4$ & $34.3 \pm 3.8$ & $<0.001 *$ \\
\hline Waist circumference (cm) & $104 \pm 13$ & $97.2 \pm 9.2$ & $114 \pm 11$ & $<0.001 *$ \\
\hline Hip circumference $(\mathrm{cm})$ & $108 \pm 9$ & $103 \pm 6.1$ & $114 \pm 7.6$ & $<0.001 *$ \\
\hline$W H R$ & $0.97 \pm 0.07$ & $0.95 \pm 0.07$ & $1.0 \pm 0.07$ & $0.034 *$ \\
\hline Atrial fibrillation (\%) & $4(7)$ & $3(9)$ & $1(4)$ & 0.631 \\
\hline Arterial hypertension (\%) & $38(67)$ & $20(61)$ & $18(75)$ & 0.394 \\
\hline$C A D(\%)$ & $35(61)$ & $21(64)$ & $14(58)$ & 0.785 \\
\hline$T 2 D M(\%)$ & $18(32)$ & $9(27)$ & $9(38)$ & 0.565 \\
\hline HDL ( $\mathrm{mmol} / \mathrm{l})$ & $1.1 \pm 0.4$ & $1.2 \pm 0.5$ & $1.0 \pm 0.2$ & 0.262 \\
\hline$L D L(\mathrm{mmol} / \mathrm{l})$ & $2.2 \pm 0.7$ & $2.0 \pm 0.6$ & $2.5 \pm 0.9$ & $0.027 *$ \\
\hline Triglycerides (mmol/l) & $1.5 \pm 0.8$ & $1.3 \pm 0.5$ & $1.7 \pm 1.0$ & 0.165 \\
\hline Total cholesterol ( $\mathrm{mmol} / \mathrm{l})$ & $4 \pm 0.9$ & $3.8 \pm 0.8$ & $4.3 \pm 1.0$ & 0.096 \\
\hline Fasting glucose (mmol/l) & $6.9 \pm 2$ & $6.6 \pm 1.7$ & $7.3 \pm 2.3$ & 0.287 \\
\hline $\mathrm{HbAlc}(\mathrm{mmol} / \mathrm{mol})$ & $43 \pm 10.1$ & $41 \pm 6.9$ & $46 \pm 13$ & 0.105 \\
\hline$C R P(\mu g / m l)$ & $7.1 \pm 10.1$ & $5 \pm 9.4$ & $8.3 \pm 10.8$ & 0.604 \\
\hline Atherogenity index & $2.6 \pm 0.9$ & $2.4 \pm 0.7$ & $2.9 \pm 0.7$ & 0.153 \\
\hline
\end{tabular}

Values are mean \pm standard deviation $(\mathrm{SD})$ unless otherwise indicated. $\mathrm{AF}=$ atrial fibrillation; BMI = body mass index; WHR = waistto-hip ratio, $\mathrm{HDL}=$ high-density lipoprotein; $\mathrm{LDL}=$ low-density lipoprotein; $\mathrm{CRP}=\mathrm{C}$-reactive protein; $\mathrm{ApoB}=\mathrm{apolipoprotein} \mathrm{B}$; $\mathrm{HbA1C}$ $=$ glycated hemoglobin. * significant results. Student's t-test and Chi-square test.

Analogously, samples of RA, SAT and EAT were obtained at the beginning of surgery from approximately the same location in all patients and from tissue not previously traumatized mechanically or by cauterization to avoid the influence of local damage. EAT was taken from the anterior interventricular sulcus or the right margin of the heart and SAT was obtained from the sternotomy site.

\section{Histology and immunohistochemistry}

Samples of RA, SAT and EAT were immediately fixed in $4 \%$ paraformaldehyde, processed, embedded in paraffin, sectioned and stained with hematoxylin-eosin. Type, amount and integrity of tissue was determined and in accordance with this evaluation, the specimens were used for immunohistochemistry.

For indirect immunohistochemical method, $7 \mu \mathrm{m}$ thick sections were used. The sections were deparaffinized and immersed into preheated antigenretrieval solution. Tris-chelaton III ( $\mathrm{pH} \mathrm{8.5)} \mathrm{was} \mathrm{used} \mathrm{for}$ the anti-human mast cell tryptase and anti-CD117 antibodies. Sodium citrate ( $\mathrm{pH}$ 6.0) was used for anti- chymase antibody. Then the samples were incubated at $98{ }^{\circ} \mathrm{C}$ for $10 \mathrm{~min}$ and allowed to cool to room temperature. The endogenous peroxidase activity and the non-specific antibody binding sites were blocked with $5 \%$ goat or bovine serum in Phosphate Buffered Saline (PBS). The mouse monoclonal anti-human mast cell tryptase (Dako, Denmark) diluted 1:20 000 in PBS + $1.5 \%$ normal goat serum, goat polyclonal anti-mast cell chymase antibody (Abcam, UK) diluted 1:1000 in PBS + $1.5 \%$ normal rabbit serum and rabbit polyclonal antihuman CD 117 antibody (Dako, Denmark diluted 1:2000 in PBS $+1.5 \%$ normal goat serum were used as primary antibodies. Visualization was achieved using LSAB+ Dako REAL TM Detection System, Peroxidase/DAB+, Rabbit/Mouse or using rabbit anti-goat biotinylated secondary antibody followed by Vectastain ABC kit peroxidase. The nuclei were counterstained by Harris's hematoxylin.

For dual immunofluorescence labeling of mast cell tryptase and chymase, we used anti-human mast cell tryptase antibody diluted 1:400 and goat polyclonal antimast cell chymase antibody diluted 1:400 in PBS $+1.5 \%$ 
normal rabbit serum. Secondary antibodies were rabbit anti-mouse Alexa Fluor 647 (Invitrogen) and rabbit antigoat Cy3 (Jackson Immunoresearch, UK) diluted 1:500 in PBS $+5 \%$ normal rabbit serum. The nuclei were stained with DAPI.

For dual immunofluorescence labeling of mast cell tryptase and CD117, we used anti-human mast cell tryptase antibody diluted $1: 400$ and rabbit polyclonal anti-CD117 antibody diluted $1: 400$ in PBS $+1.5 \%$ normal goat serum. Secondary antibodies were goat antimouse Alexa Fluor 532 (Invitrogen) and goat anti-rabbit Cy5 (Invitrogen) diluted 1:500 in in PBS $+5 \%$ normal goat serum. The nuclei were stained with DAPI.

\section{Quantification of mast cells}

For quantification, we used samples immunolabeled for mast cell tryptase. We obtained 40 images collected via a systematic random sampling from each tissue section (one tissue section/patient) using the 20x dry objective of the Leica DMLB microscope (Leica Microsystems GmbH, Wetzlar, Germany). The number of mast cells was assessed by manual analysis of microscopic images using Image J $1.50 \mathrm{i}$ software (National Institutes of Health, USA). Dense connective tissue, empty fields and bigger blood vessels were excluded from the area of given image.

\section{Measurement of adipocyte size}

For the measurement of adipocyte size, we used the same slides as those for quantification of mast cells. The measurement included cells, which had their complete cell body in the image and the diameter was measured across the adipocyte cells cytoplasm intersecting with adipocyte nucleus. We measured diameter of approximately 30 cells in each section. One section represented one patient.

\section{Statistical analysis}

Statistical analysis was performed by unpaired t-test, Chi-square test, Mann-Whitney rank sum test. Statistical significance was assigned to $\mathrm{p}<0.05$.

\section{Results}

\section{Clinical characteristics of patients}

Clinical characteristics of the whole group and of non-CAD patients $(n=22)$ and CAD patients $(n=35)$ are summarized in Table 1 . No statistically significant differences in the indicated parameters were detected between these 2 groups of patients.
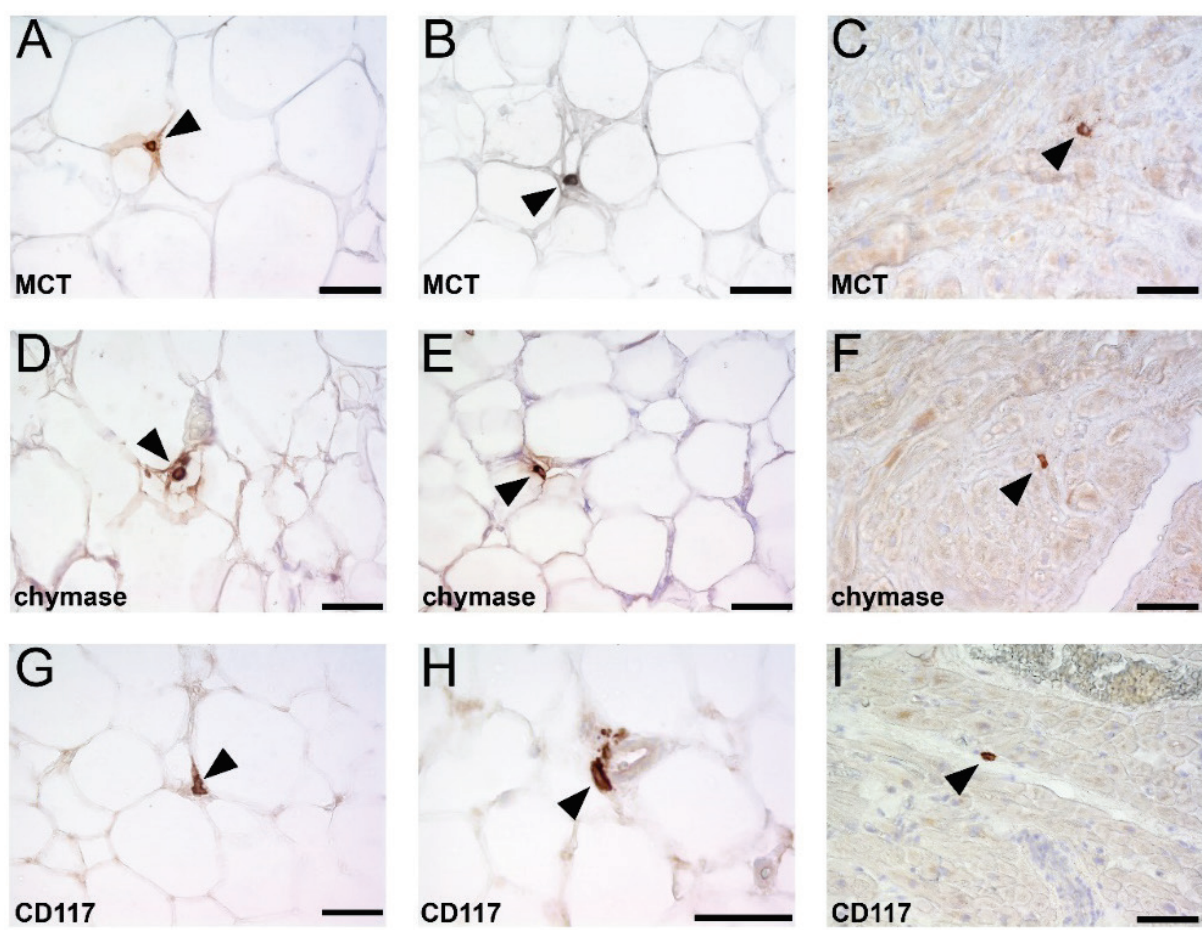

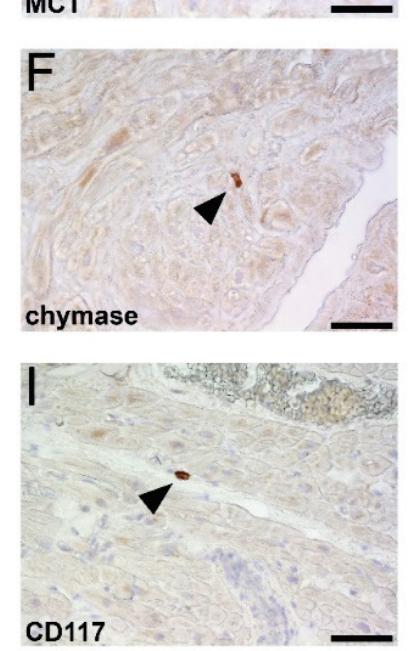

Fig. 1. Immunohistochemical detection of mast cell tryptase, chymase and CD117 in SAT, EAT and RA. (A-C) Images showing a result of immunoperoxidase reaction for mast cell tryptase (MCT). (A) Solitary immunoreactive cell (arrowhead) in SAT is localized between adipocytes. (B) A single immunoreactive cell (arrowhead) close to a small blood vessel in EAT sample. (C) Solitary immunoreactive cell (arrowhead) in the myocardial interstitium of RA. Scale bar in $A-C=50 \mu \mathrm{m}$. (D-F) Images showing a result of immunoperoxidase reaction for chymase. (D) A single immunoreactive cell (arrowhead) close to an arteriole in the sample of SAT. (E) Solitary immunoreactive cell (arrowhead) in EAT is localized between adipocytes. (F) Solitary immunoreactive cell (arrowhead) in the myocardial interstitium of RA. Scale bar in $D-F=50 \mu m$. (G-I) Images showing a result of immunoperoxidase reaction for

CD117. (G) Solitary immunoreactive cell (arrowhead) in SAT is localized between adipocytes. (H) An immunoreactive cell with granules (arrowhead) close to a small arteriole in EAT sample. (I) Solitary immunoreactive cell (arrowhead) in the myocardial interstitium of RA. Scale bar in G-I=50 $\mu \mathrm{m}$. 


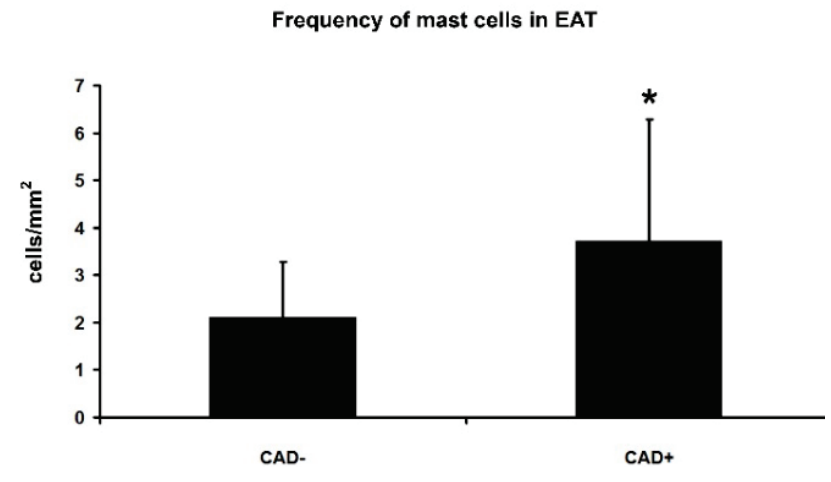

Fig. 2. Quantification of mast cell tryptase-positive cells in EAT. A graph showing frequency of mast cell tryptase-positive mast cells in EAT of CAD patients and non-CAD patients. An average number of mast cell-positive cells per square $\mathrm{mm}$ of crosssectioned adipose tissue is given $+/-$ SD. The significant result $(p>0,05)$ is marked by *. Mann-Whitney $U$ test.
Mast cells in EAT, SAT and RA of patients with obesity, $C A D$ and $T 2 D M$

Tryptase-positive mast cells were detected in all samples of EAT, SAT and RA regardless of patient group. These cells were usually scattered throughout adipose or myocardial tissue as single cells in the interstitium (Fig. 1A-C). Occasionally, small groups consisting of 2-3 cells, especially in regions of perivascular connective tissue, were detected. We quantified the number of tryptase-positive mast cells in EAT, SAT and RA samples and we compared the results between $\mathrm{CAD}$ and non-CAD patients, obese and nonobese patients and T2DM and non-T2DM patients (Table 4). We found a significantly higher number of tryptase-positive mast cells in EAT samples of CAD

Table 4. Quantification of mast cells in different patient groups and different localization.

\begin{tabular}{lcccccc}
\hline & CAD & non-CAD & obese & non-obese & T2DM & non-T2DM \\
\hline$E A T$ & $3.7 \pm 2.6^{*}$ & $2.1 \pm 1.2$ & $3.6 \pm 2.6$ & $2.9 \pm 2.0$ & $2.7 \pm 1.6$ & $3.3 \pm 2.5$ \\
$S A T$ & $3.3 \pm 2.3$ & $3.2 \pm 2.0$ & $3.5 \pm 2.3$ & $3.2 \pm 2.2$ & $3.7 \pm 2.2$ & $3.1 \pm 2.3$ \\
$R A$ & $3.4 \pm 2.6$ & $2.5 \pm 1.6$ & $3.4 \pm 2.5$ & $2.8 \pm 2.0$ & $3.3 \pm 2.0$ & $3.0 \pm 2.4$ \\
\hline
\end{tabular}

Values are mean \pm standard deviation (SD) unless otherwise indicated. EAT = epicardial adipose tissue, SAT = subcutaneous adipose tissue, RA = right atrial myocardium. * significant result $(p<0.05)$, Mann-Whitney $\mathrm{U}$ test.
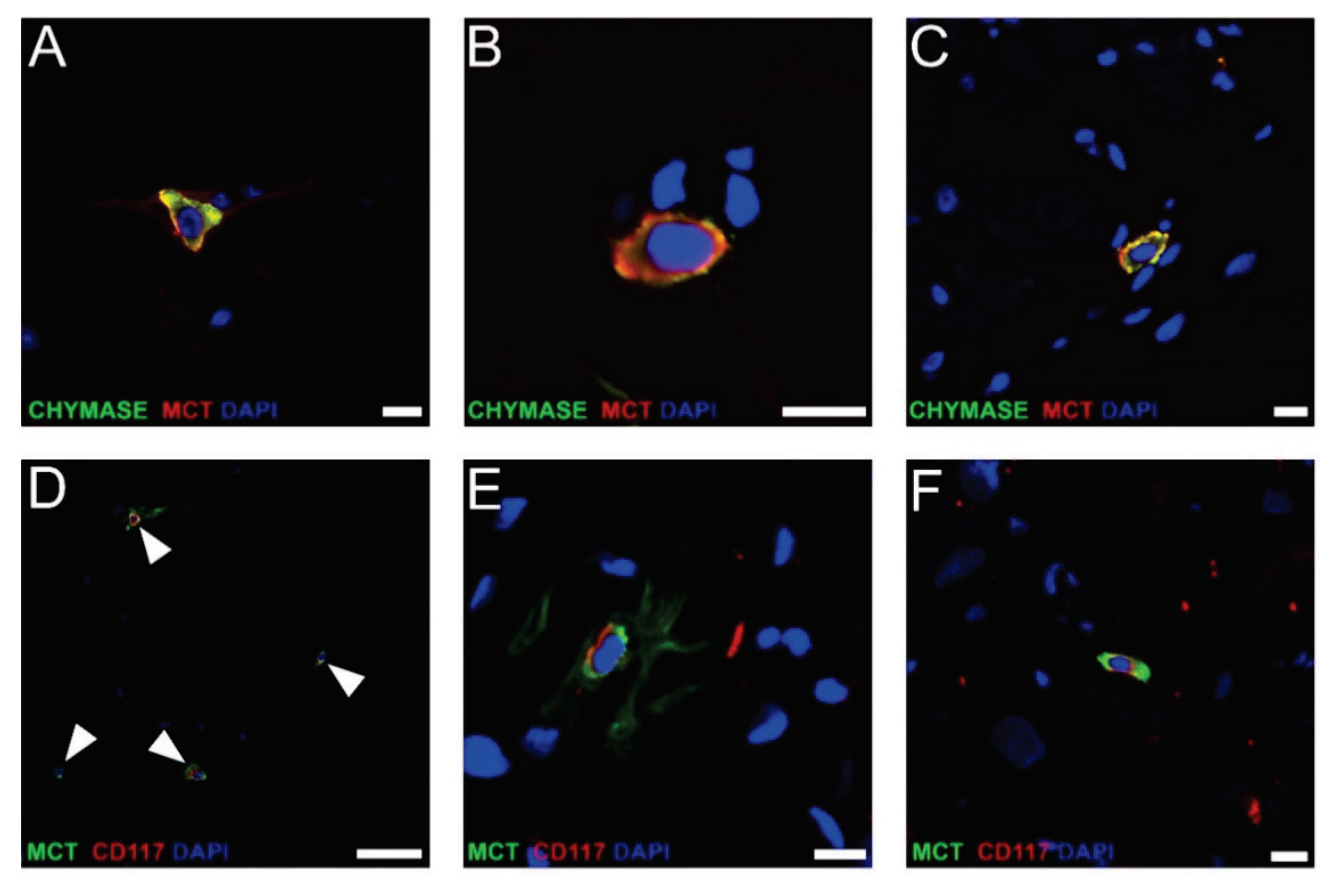
CD117. (D) CD117 (red) is expressed in tryptase-positive (green) mast cells (arrowheads) localized in the interstitial spaces between adipocytes in SAT. Scale bar $=50 \mu \mathrm{m}$. (E) A confocal image of a mast cell in EAT co-expressing CD117 (red) and mast cell tryptase (green). Scale bar=10 $\mu \mathrm{m}$. (F) CD117 (red) is expressed in mast cell tryptase-positive mast cell (green) localized in the endomysium of RA myocardium. Nuclei are stained with DAPI (blue). Scale bar $=10 \mu \mathrm{m}$. 
patients compared to non-CAD patients (Table 4, Fig. 2). There was no statistically significant difference in the number of tryptase-positive mast cells in EAT when obese and non-obese and T2DM and non-T2DM patients were compared and neither in other anatomical locations we found significant differences between selected groups of patients (Table 4).

Further characterization of mast cell populations in EAT, SAT and RA

To characterize mast cell population in EAT, SAT and RA based on expression of some other mast cell markers we performed immunohistochemical detection of chymase and CD117. Chymase-positive cells had similar morphology and localization pattern like tryptase-positive mast cells. They were detected in all patient samples from all anatomical locations (Fig. 1 D-F). To confirm the identity of these cells, we performed a dual immunofluorescence labeling using antibodies against chymase and tryptase (Fig. 3A-C). Double-positive cells were detected in all tissue samples from all patients. No cells were positive for only one cell marker and all double-positive cells displayed mast cell morphology.

Using antibody against CD117 marker, we observed cells in the SAT, EAT as well as in RA that corresponded to mast cells based on their localization and morphology (Fig. 1G-I). To verify the localization of CD117 immunoreactivity, a dual immunofluorescence labeling of CD117 and mast cell tryptase were performed. In all samples of SAT, EAT and RA, only CD117/mast cell tryptase-double positive cells were found (Fig. 3D-F).

The higher number of mast cells could possibly be a result of changes in adipocyte diameter in EAT during CAD that would lead to a relative expansion of interstitial connective tissue. We measured adipocyte diameter on fraction of samples and we did not find a significant difference between adipocyte diameter in EAT, when CAD and non-CAD patients were compared (data not shown).

\section{Discussion}

Immune cells of various types are part of white adipose tissue and their numbers change during chronic inflammation of adipose tissue, which accompanies obesity and some other related pathologies (Dam et al. 2016). In this study, mast cell numbers and phenotype were evaluated in SAT, EAT as well as in atrial myocardium of patients undergoing heart surgery. We found a higher infiltration of mast cells in EAT of patients with CAD compared with non-CAD patient group. In addition, mast cells in adipose tissue and myocardium displayed characteristic markers of $\mathrm{MC}_{\mathrm{TC}}$ population and all mast cells were positive for CD117 marker. No other CD117+ cells were detected in these samples.

This is the first report of mast cells number in EAT of patients with CAD, obesity or T2DM. Mast cells were previously recognized as part of the inflammatory cell infiltrate in EAT of CAD patients but comparison of their number between $\mathrm{CAD}$ and non-CAD groups were not performed (Mazurek et al. 2003). The increased infiltration of mast cells in CAD patients corresponds to findings in other inflammatory cell populations. Macrophages are elevated in EAT of CAD patients as shown in previous reports (Hirata et al. 2011). The chronic inflammatory process in EAT during CAD is not only accompanied by an increase of the total number of macrophages, but there is also a shift towards a pro-inflammatory phenotype (Gurses et al. 2016, Vianello et al. 2016). Such pro-inflammatory macrophages form a typical morphological feature of adipose tissue called crown-like structures, which are characteristic for EAT during CAD (Pierzynova et al. 2019). In diet-induced obese mice, mast cells associate with CLS (Altintas et al. 2011), but in adipose tissue samples of CAD patients we did not observe such tendency. Also T-lymphocytes are elevated in EAT of patients with CAD (Mraz et al. 2019). Thus, based on these reports, the elevated mast cell numbers in EAT of CAD patients suggest their involvement in chronic adipose tissue inflammation together with other cells responsible for both innate as well as acquired immunity.

Mast cells were investigated in association with CAD due to their infiltration of the coronary artery wall (Kovanen and Bot 2017). They are implicated in several different steps along the progression of atherosclerotic process. Their numbers are increased in the intima and other layers of the coronary artery wall and they can act by secretion of both pre-formed as well as newly synthesized factors (Theoharides et al. 2011). The potential mechanisms that can be attributed to mast cell effects on atherosclerotic process are stimulation of leukocyte immigration, an increase of vascular permeability facilitating lipoprotein accumulation, foam cell formation and foam cell apoptosis, apoptosis of endothelial cells leading to vascular wall erosion and 
thrombosis, effects promoting plaque destabilization and rupture such as apoptosis of smooth muscle cells, collagen proteolysis and stimulation of neoangiogenesis and intraplaque hemorrhage from fragile microvessels (Kovanen 2019). Based on our findings it is likely that the inflammatory process does not affect the vascular wall only, but it spreads throughout the periadventitial adipose tissue into the surrounding EAT. The main finding of our study is an increase of mast cell number in EAT of CAD patients and this can be the result of increased mast cell migration into EAT. Although the principle chemoattractant and driver of mast cell proliferation is stem cell factor (Okayama and Kawakami 2006), it was reported that also adipokines such as leptin can stimulate mast cell migratory response (Hristova 2001, Zelechowska et al. 2019). This is quite likely scenario, because leptin production is increased in EAT of CAD patients (Cheng et al. 2008, Gruzdeva et al. 2017). The question of mast cell stimulation during atherosclerosis is best answered in studies dealing with mast cell activity within the atherosclerotic coronary wall (Kovanen and Bot 2017). Coronary artery mast cells can be stimulated by immune complexes of $\operatorname{IgG}$ with oxidized LDL particles (Lappalainen et al. 2011), complement system (Laine et al. 2002), neuropeptides secreted from nerve endings in the coronary artery adventitia (Laine et al. 2000, Bot et al. 2010), CRH released during stress (Alevizos et al. 2014) and TLR-4 ligands such as oxidized LDL (Meng et al. 2013). Hypothetical stimuli of mast cells residing in the pericoronary EAT may include those mentioned above, but EAT mast cells can be also stimulated by an excess FFA, possibly acting thorough TLR binding of FFA (Agier et al. 2018, Rogero and Calder 2018, Iacobellis and Barbaro 2019). Furthemore adipokines secreted by EAT may also stimulate the secretory activity of mast cells (Zelechowska et al. 2019). The question whether the inflammation starts in the EAT or in the vascular wall cannot be resolved based on our observational study since we analyzed patients with a previous history of CAD. Most likely, there is a bidirectional signaling and inflammatory cell migration between the atherosclerotic artery and the surrounding adipose tissue. Increased infiltration of mast cells in EAT perpetuates a chronic inflammatory state of adipose tissue and while the activity of mast cells within the coronary artery wall have more direct influence on atherosclerotic process (Kovanen 2019), mast cells in EAT might act indirectly. Through secretion of several different factors, mast cells can stimulate T-lymphocytes (Hershko and Rivera 2010) and they activate macrophages as well (Xu and Shi 2012). Both macrophages and T-lymphocytes were repeatedly implicated in chronic inflammation of EAT associated with CAD and other pathologies (Hirata et al. 2011, Gurses et al. 2016, Vianello et al. 2016, Mraz et al. 2019). In contrast to EAT, in the SAT it was found previously that mast cell numbers increase in certain pathological conditions and contribute to the chronic inflammation of adipose tissue (Zelechowska et al. 2018). The study of mast cells in adipose tissue during obesity was initiated both in humans as well as in experimental animals by observations of mast cell increase in obesity (Liu et al. 2009). In contrast to this and another report (Spencer et al. 2014), we did not find any difference in mast cell numbers between obese and non-obese patients undergoing heart surgery neither in SAT nor in EAT. This can be due to differences in the study population or the specific SAT depot used for analysis in our and other studies. Interestingly, in diet-induced obese mice there was no difference between mast cell numbers in SAT depots, but obese mice had more mast cells in mesenteric, perinephric and epididymal fat (Altintas et al. 2011). Furthemore, in a human study, no difference between mast cell numbers was found when both subcutaneous as well as omental adipose tissue was compared between obese and lean subjects (Divoux et al. 2012). Nevertheless, there was an increased mast cell infiltration of both adipose tissue depots in obese diabetic patients compared to lean and obese non-diabetic patients. In our study, we could not subdivide obese patient group according to presence of diabetes due to the low number of patients enrolled.

For the quantitative analysis we used tryptase as a well-accepted and ubiquitous marker of mast cells (da Silva et al. 2014). To further characterize mast cell population in the adipose tissue and myocardium, we also performed the detection of chymase and we document that mast cells in these locations belong to $\mathrm{MC}_{\mathrm{TC}}$ population typically found for example in the skin. We also evaluated the expression of CD117 in the samples of EAT, SAT and in the myocardium. Although CD117 is also well-known marker of mast cells, there are reports of other CD117+ cells in the heart as well as in the epicardium, which are by some authors considered as a special type of cells called telocytes (Popescu et al. 2010, Varga et al. 2017). In addition, in the heart, CD117 marker was reported to be present in cardiac stem or progenitor cells (Bearzi et al. 2007). The use of CD117 as 
a marker of telocytes or marker of cardiac stem cells was questioned in other reports (Zhou et al. 2010, Iancu et al. 2019) and based on the results of double-labeling immunohistochemistry performed in the present study, we can conclude that the great majority of CD117+ cells in SAT, EAT and atrial myocardium are mast cells.

This study focused on the quantitation of mast cells in EAT, SAT and myocardium. We characterized mast cell population only partially with respect to several mast cell markers. Nevertheless, these findings open up possibility of further studies focusing on detection of specific secretory products of mast cells in EAT during CAD.

In conclusion, our data support the concept that mast cells constitute an important part of inflammatory cell infiltration of EAT associated with CAD. The specific role of EAT-based mast cells during atherosclerotic process has to be further investigated, possibly through not only advanced experimental animal studies but also prospective human studies.

\section{Conflict of Interest}

There is no conflict of interest.

\section{Acknowledgements}

Supported by Ministry of Health, Czech Republic conceptual development of research organization (,Institute for Clinical and Experimental Medicine IKEM, IN 00023001“), grant AZV NV19-02-00118, RVO VFN 64165 and PROGRES Q25. We would like to thank Ing. Lucie Kosová and Ms. Marcela Blažkeová for processing the samples.

\section{References}

AGIER J, PASTWINSKA J, BRZEZINSKA-BLASZCZYK E: An overview of mast cell pattern recognition receptors. Inflamm Res 67: 737-746, 2018. https://doi.org/10.1007/s00011-018-1164-5

ALEVIZOS M, KARAGKOUNI A, PANAGIOTIDOU S, VASIADI M, THEOHARIDES TC: Stress triggers coronary mast cells leading to cardiac events. Ann Allergy Asthma Immunol 112: 309-316, 2014. https://doi.org/10.1016/j.anai.2013.09.017

ALTINTAS MM, AZAD A, NAYER B, CONTRERAS G, ZAIAS J, FAUL C, REISER J, NAYER A: Mast cells, macrophages, and crown-like structures distinguish subcutaneous from visceral fat in mice. J Lipid Res 52: 480-488, 2011. https://doi.org/10.1194/jlr.M011338

BEARZI C, ROTA M, HOSODA T, TILLMANNS J, NASCIRNBENE A, DE ANGELIS A, YASUZAWA-AMANO S, TROFIMOVA I, SIGGINS RW, LECAPITAINE N, CASCAPERA S, BELTRAMI AP, D'ALESSANDRO DA, ZIAS E, QUAINI F, URBANEK K, MICHLER RE, BOLLI R, KAJSTURA J, LERI A, ANVERSA P: Human cardiac stem cells. Proceedings of the National Academy of Sciences of the United States of America 104: 14068-14073, 2007. https://doi.org/10.1073/pnas.0706760104

BOT I, DE JAGER SC, BOT M, VAN HEININGEN SH, DE GROOT P, VELDHUIZEN RW, VAN BERKEL TJ, VON DER THUSEN JH, BIESSEN EA: The neuropeptide substance P mediates adventitial mast cell activation and induces intraplaque hemorrhage in advanced atherosclerosis. Circ Res 106: 89-92, 2010. https://doi.org/10.1161/CIRCRESAHA.109.204875

DA SILVA EZ, JAMUR MC, OLIVER C: Mast cell function: a new vision of an old cell. J Histochem Cytochem 62: 698-738, 2014. https://doi.org/10.1369/0022155414545334

DAM V, SIKDER T, SANTOSA S: From neutrophils to macrophages: differences in regional adipose tissue depots. Obes Rev 17: 1-17, 2016. https://doi.org/10.1111/obr.12335

DivouX A, MOUTEL S, POITOU C, LACASA D, VEYRIE N, AISSAT A, AROCK M, GUERRE-MILLO M, CLEMENT K: Mast cells in human adipose tissue: link with morbid obesity, inflammatory status, and diabetes. J Clin Endocrinol Metabol 97: E1677-E1685, 2012. https://doi.org/10.1210/jc.2012-1532

FITZGIBBONS TP, CZECH MP: Epicardial and perivascular adipose tissues and their influence on cardiovascular disease: basic mechanisms and clinical associations. J Am Heart Assoc 3: e000582, 2014. https://doi.org/10.1161/JAHA.113.000582

GRUZDEVA OV, AKBASHEVA OE, DYLEVA YA, ANTONOVA LV, MATVEEVA VG, UCHASOVA EG, FANASKOVA EV, KARETNIKOVA VN, IVANOV SV, BARBARASH OL: Adipokine and cytokine profiles of epicardial and subcutaneous adipose tissue in patients with coronary heart disease. Bull Exp Biol Med 163: 608-611, 2017. https://doi.org/10.1007/s10517-017-3860-5 
GURSES KM, OZMEN F, KOCYIGIT D, YERSAL N, BILGIC E, KAYA E, KOPRU CZ, SOYAL T, DOGANCI S, TOKGOZOGLU L, KORKUSUZ P: Netrin-1 is associated with macrophage infiltration and polarization in human epicardial adipose tissue in coronary artery disease. J Cardiol: 2016. https://doi.org/10.1016/j.atherosclerosis.2016.07.094

HERSHKO AY, RIVERA J: Mast cell and T cell communication; amplification and control of adaptive immunity. Immunol Lett 128: 98-104, 2010. https://doi.org/10.1016/j.imlet.2009.10.013

HIRATA Y, TABATA M, KUROBE H, MOTOKI T, AKAIKE M, NISHIO C, HIGASHIDA M, MIKASA H, NAKAYA Y, TAKANASHI S, IGARASHI T, KITAGAWA T, SATA M: Coronary atherosclerosis is associated with macrophage polarization in epicardial adipose tissue. J Am Coll Cardiol 58: 248-255, 2011. https://doi.org/10.1016/j.jacc.2011.01.048

HRISTOVA M, ALOE L, GHENEV PI, FIORE M, CHALDAKOV GN: Leptin and mast cells: a novel adipoimmune link. Turk J Med Sci: 581-583, 2001.

CHENG KH, CHU CS, LEE KT, LIN TH, HSIEH CC, CHIU CC, VOON WC, SHEU SH, LAI WT: Adipocytokines and proinflammatory mediators from abdominal and epicardial adipose tissue in patients with coronary artery disease. Int J Obes (Lond) 32: 268-274, 2008. https://doi.org/10.1038/sj.ijo.0803726

IACOBELLIS G: Epicardial fat: a new cardiovascular therapeutic target. Curr Opin Pharmacol 27: 13-18, 2016. https://doi.org/10.1016/j.coph.2016.01.004

IACOBELLIS G, BARBARO G: Epicardial adipose tissue feeding and overfeeding the heart. Nutrition 59: 1-6, 2019. https://doi.org/10.1016/j.nut.2018.07.002

IANCU CB, RUSU MC, MOGOANTA L, HOSTIUC S, TOADER OD: The telocytes in the subepicardial niche. Applied Sciences-Basel 9: 2019. https://doi.org/10.3390/app9081615

KOVANEN PT: Mast cells as potential accelerators of human atherosclerosis-from early to late lesions. Int J Mol Sci 20: 2019. https://doi.org/10.3390/ijms20184479

KOVANEN PT, BOT I: Mast cells in atherosclerotic cardiovascular disease - Activators and actions. Eur J Pharmacol 816: 37-46, 2017. https://doi.org/10.1016/j.ejphar.2017.10.013

KRYSTEL-WHITTEMORE M, DILEEPAN KN, WOOD JG: Mast cell: a multi-functional master cell. Front Immunol 6: 620, 2015. https://doi.org/10.3389/fimmu.2015.00620

LAINE P, NAUKKARINEN A, HEIKKILA L, PENTTILA A, KOVANEN PT: Adventitial mast cells connect with sensory nerve fibers in atherosclerotic coronary arteries. Circulation 101: 1665-1669, 2000. https://doi.org/10.1161/01.CIR.101.14.1665

LAINE P, PENTIKAINEN MO, WURZNER R, PENTTILA A, PAAVONEN T, MERI S, KOVANEN PT: Evidence for complement activation in ruptured coronary plaques in acute myocardial infarction. Am J Cardiol 90: 404-408, 2002. https://doi.org/10.1016/S0002-9149(02)02498-0

LAPPALAINEN J, LINDSTEDT KA, OKSJOKI R, KOVANEN PT: OxLDL-IgG immune complexes induce expression and secretion of proatherogenic cytokines by cultured human mast cells. Atherosclerosis 214: 357-363, 2011. https://doi.org/10.1016/j.atherosclerosis.2010.11.024

LEE MJ, WU Y, FRIED SK: Adipose tissue heterogeneity: implication of depot differences in adipose tissue for obesity complications. Mol Aspects Med 34: 1-11, 2013. https://doi.org/10.1016/j.mam.2012.10.001

LIU J, DIVOUX A, SUN J, ZHANG J, CLEMENT K, GLICKMAN JN, SUKHOVA GK, WOLTERS PJ, DU J, GORGUN CZ, DORIA A, LIBBY P, BLUMBERG RS, KAHN BB, HOTAMISLIGIL GS, SHI GP: Genetic deficiency and pharmacological stabilization of mast cells reduce diet-induced obesity and diabetes in mice. Nat Med 15: 940-945, 2009. https://doi.org/10.1038/nm.1994

MATLOCH Z, CINKAJZLOVA A, MRAZ M, HALUZIK M: The role of inflammation in epicardial adipose tissue in heart diseases. Curr Pharm Des 24: 297-309, 2018a. https://doi.org/10.2174/1381612824666180110102125

MATLOCH Z, KRATOCHVÍLOVÁ H, CINKAJZLOVÁ A, LIPŠ M, KOPECKÝ P, POŘÍZKA M, HALUZÍKOVÁ D, LINDNER J, MRÁZ M, KLOUČKOVÁ J, LACINOVÁ Z, HALUZÍK M: Changes in omentin levels and its mrna expression in epicardial adipose tissue in patients undergoing elective cardiac surgery: the influence of Type 2 diabetes and coronary heart disease. Physiol Res 67: 881-890, $2018 \mathrm{~b}$. https://doi.org/10.33549/physiolres.933909. 
MAZUREK T, ZHANG L, ZALEWSKI A, MANNION JD, DIEHL JT, ARAFAT H, SAROV-BLAT L, O'BRIEN S, KEIPER EA, JOHNSON AG, MARTIN J, GOLDSTEIN BJ, SHI Y: Human epicardial adipose tissue is a source of inflammatory mediators. Circulation 108: 2460-2466, 2003. https://doi.org/10.1161/01.CIR.0000099542.57313.C5

MENG Z, YAN C, DENG Q, DONG X, DUAN ZM, GAO DF, NIU XL: Oxidized low-density lipoprotein induces inflammatory responses in cultured human mast cells via Toll-like receptor 4. Cell Physiol Biochem 31: 842-853, 2013. https://doi.org/10.1159/000350102

MRAZ M, CINKAJZLOVA A, KLOUCKOVA J, LACINOVA Z, KRATOCHVILOVA H, LIPS M, PORIZKA M, KOPECKY P, PIERZYNOVA A, KUCERA T, MELENOVSKY V, STRIZ I, LINDNER J, HALUZIK M: Coronary artery disease is associated with an increased amount of $t$ lymphocytes in human epicardial adipose tissue. Mediators Inflamm: 2019. https://doi.org/10.1155/2019/4075086

MRAZ M, HALUZIK M: The role of adipose tissue immune cells in obesity and low-grade inflammation. J Endocrinol 222: R113-127, 2014. https://doi.org/10.1530/JOE-14-0283

OKAYAMA Y, KAWAKAMI T: Development, migration, and survival of mast cells. Immunol Res 34: 97-115, 2006. https://doi.org/10.1385/IR:34:2:97

PIERZYNOVA A, SRAMEK J, CINKAJZLOVA A, KRATOCHVILOVA H, LINDNER J, HALUZIK M, KUCERA $\mathrm{T}$ : The number and phenotype of myocardial and adipose tissue CD68+ cells is associated with cardiovascular and metabolic disease in heart surgery patients. Nutr Metab Cardiovasc Dis 29: 946-955, 2019. https://doi.org/10.1016/j.numecd.2019.05.063

POPESCU LM, MANOLE CG, GHERGHICEANU M, ARDELEAN A, NICOLESCU MI, HINESCU ME, KOSTIN S: Telocytes in human epicardium. J Cell Mol Med 14: 2085-2093, 2010. https://doi.org/10.1111/j.15824934.2010.01129.x

ROGERO MM, CALDER PC: Obesity, inflammation, toll-like receptor 4 and fatty acids. Nutrients 10: 2018. https://doi.org/10.3390/nu10040432

SPENCER M, YANG L, ADU A, FINLIN BS, ZHU B, SHIPP LR, RASOULI N, PETERSON CA, KERN PA: Pioglitazone treatment reduces adipose tissue inflammation through reduction of mast cell and macrophage number and by improving vascularity. PLoS One 9: e102190, 2014. https://doi.org/10.1371/journal.pone.0102190

THEOHARIDES TC, SISMANOPOULOS $\mathrm{N}$, DELIVANIS DA, ZHANG B, HATZIAGELAKI EE, KALOGEROMITROS D: Mast cells squeeze the heart and stretch the gird: their role in atherosclerosis and obesity. Trends Pharmacol Sci 32: 534-542, 2011. https://doi.org/10.1016/j.tips.2011.05.005

VARGA I, KYSELOVIC J, DANIHEL L, KLEIN M, BARCZI T, GALFIOVA P, DANISOVIC L: Cardiac telocytes as principal interstitial cells for myocardial reparation and regeneration after infarction - our hope. Bratisl Lek Listy 118: 721-723, 2017. https://doi.org/10.4149/BLL_2017_136

VIANELLO E, DOZIO E, ARNABOLDI F, MARAZZI MG, MARTINELLI C, LAMONT J, TACCHINI L, SIGRUNER A, SCHMITZ G, CORSI ROMANELLI MM: Epicardial adipocyte hypertrophy: Association with M1-polarization and toll-like receptor pathways in coronary artery disease patients. Nutr Metab Cardiovasc Dis 26: 246-253, 2016. https://doi.org/10.1016/j.numecd.2015.12.005

XU JM, SHI GP: Emerging role of mast cells and macrophages in cardiovascular and metabolic diseases. Endocrine Rev 33: 71-108, 2012. https://doi.org/10.1210/er.2011-0013

ZELECHOWSKA P, AGIER J, KOZLOWSKA E, BRZEZINSKA-BLASZCZYK E: Mast cells participate in chronic low-grade inflammation within adipose tissue. Obes Rev 19: 686-697, 2018. https://doi.org/10.1111/obr.12670

ZELECHOWSKA P, BRZEZINSKA-BLASZCZYK E, WIKTORSKA M, ROZALSKA S, WAWROCKI S, KOZLOWSKA E, AGIER J: Adipocytokines leptin and adiponectin function as mast cell activity modulators. Immunology 158: 3-18, 2019. https://doi.org/10.1111/imm.13090

ZHOU Y, PAN P, YAO L, SU M, HE P, NIU N, MCNUTT MA, GU J: CD117-positive cells of the heart: progenitor cells or mast cells? J Histochem Cytochem 58: 309-316, 2010. https://doi.org/10.1369/jhc.2009.955146 